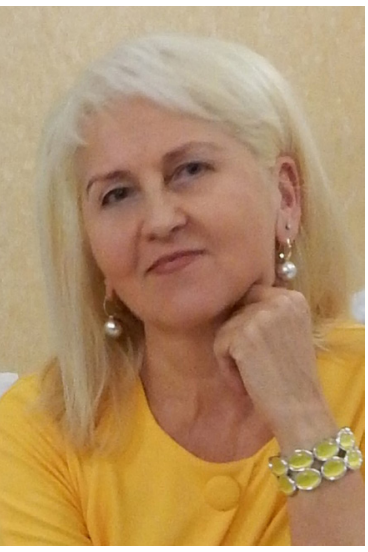

\author{
Ірина Розман, \\ кандидат педагогічних наук, доцент кафедри \\ філологічних дисциплін та соціальних комунікацій, \\ Мукачівський державний університет \\ (м. Мукачево, Україна) \\ Iryna Rozman, \\ PhD in Education, Associate Professor, Department of \\ Philology and Social Communications, \\ Mukachevo State University \\ (Mukachevo, Ukraine) \\ rozmanii@ukr.net
}

ORCID ID 0000-0002-4951-0074

Удк 016: 01 (477)

\title{
THE PROBLEM OF PERIODIZATION OF PEDAGOGICAL PERSONNEL STUDY
}

Abstract. The article is devoted to the analysis of the problem of periodization of the research of pedagogical personnel. The theoretical and methodological approaches of Ukrainian and foreign scientists to the periodization of the development of historical and pedagogical science, which are based in general on the technologies of using the methodological tools of historical science, are determined. The role, significance, potential of comparative - historical, comparative, and other methods that are used in studies devoted to life and various directions of creative and social activity of pedagogical personalities are described.

Two methodologically important approaches are found for conducting studies in the field of pedagogical biography, which are related to the study of a person in a universal coordinate system: a synchronous system, projecting its analysis in a specific time period and diachronic, projecting the study of personalities in a time «vertical».

Disadvantages of periodization as an instrument and means of scientific and cognitive activities are shown; the ways and possibilities of their minimization and increase of the scientific and heuristic efficiency of the periodization method are determined in the studied periods (stages) of the life path of the pedagogical personalities. The article substantiates the position according to which the correct application of methodological tools allows to avoid various manifestations of dichotomy (illicit division) in pedagogical and biographical research.

Keywords: methodology of pedagogical science, pedagogical biography, pedagogical personality, periodization, comparative historical method.

\section{ПРОБЛЕМА ПЕРІОДИЗАЦІЇ ДОСЛІДЖЕННЯ ПЕДАГОГІЧНОЇ ПЕРСОНАЛІЇ}

Анотація. Стаття присвячена аналізу періодизації дослідження педагогічної персоналії. 3'ясовано теоретикометодологічні підходи українських і зарубіжних учених до періодизації розвитку історико-педагогічної науки, які загалом ґрунтуються на технологіях використання методологічного інструментарію історичної науки. Схарактеризовано роль, значення, потенційні можливості порівняльно-історичного, порівняльного, інших методів, що використовуються у дослідженнях, присвячених життю та різним напрямам творчої і суспільної діяльності педагогічних персоналій.

Визначено два методологічно важливі підходи проведення досліджень у галузі педагогічної біографістики, які стосуються вивчення особи в універсальній системі координат: синхронній, яка проектує її аналіз у певний конкретний відрізок часу, та діахронній, що проектує вивчення персоналії за часовою «вертикаллю».

Показано недоліки періодизації як інструмента і засобу науково-пізнавальної діяльності; визначено шляхи і можливості їхньої мінімізації та підвищення науково-евристичної ефективності методу періодизації при визначенні періодів (етапів) життєвого шляху педагогічних персоналій. Обґрунтовано позицію, згідно 3 якою правильне застосування методологічного інструментарію дозволяє уникати різних проявів дихотомії (неправомірності поділу) у педагогічно-біографічних дослідженнях.

Ключові слова: методологія педагогічної науки, педагогічна біографістика, педагогічна персоналія, періодизація, порівняльно-історичний метод.

\section{INTRODUCTION}

Periodization is an important and virtually compulsory component of historical and pedagogical research. Olga Sukhomlynska considers it one of the main scientific problems of the humanitarian sphere, because from the fact that the periodization is taken as the basis of the period, which context is invested in one or another period, acting as its driving force, the deployment of a common research field is taking place. A clear periodization, in the opinion of the scientist, helps to understand the structural features of science, the genesis and the evolution of its ideas, concepts, methods, 
trends of development; facilitates the detection of its internal laws, provides scientific generalization (Sukhomlynsjka O.V., 2002, p. 37-39).

The precede information applies in full to pedagogical biography, which comprehensively comprehends the formation, formation, development of the personalities of more or less well-known teacher, scientist, educator, public figure in interdependence with other environmental factors, covering both external socio-political conditions, and close socio-cultural environment. It actualizes the elucidation of theoretical and theoretical approaches to the development of the periodization of their life, since many scholars solve this problem, relying solely on general logicminded constructs and their own intuition and experience.

Analysis of scientific research. Modern Ukrainian and foreign scholars, in particular, historians of pedagogy (M. Volikova, N. Gupan, N. Dichek, I. Kovalchenko, A.Nagorny, L. Natochiy, A. Pershukova T. Popova, I. Strazhnikova, O. Sukhomlynska, O.Shkola, etc.) accumulated valuable scientific and methodological experience in developing research tools on the definition of approaches, criteria and other aspects of the definition and characteristics of the periods of the historical-pedagogical process and the development of education and pedagogy in Ukraine and abroad. However, the theoretical and methodological principles of the periodization of the research of pedagogical personalities are insufficiently studied, which determines the need for substantive clarification of this problem.

AIM AND TASKS RESEARCH is to analyze the accumulated scientific and methodological experience of periodization of the historical and pedagogical process accumulated by Ukrainian and foreign scientists and to determine the possibilities of its creative use in studying the life of pedagogical personalities.

\section{RESEARCH RESULTS}

An important prerequisite for solving this task is to find out the essence and technologies of using methodological tools, primarily historical science, which has accumulated considerable experience in developing the theory and practice of periodization of the historical process. His scientific and theoretical basis is comparative-historical method, the content and technique of use of which are sufficiently developed in the scientific literature (Kovaljchenko Y. D., 2003, p. 182-232; Naghornykh E. E., 2002; Teoryja y metodologhyja ystoryy, 2014, p. 387-408). There are productive scientific and methodological developments concerning its application in historical and pedagogical researches ( $\mathrm{N}$. Dichek, E. Panasenko, S. Sergeeva, O. Sukhomlinska, etc.), so they can become a reliable operational tool for solving tasks of pedagogical biography.

The comparative-historical (historical - comparative analysis shows that in this case, the inversion does not change the essence. - I.R.), the method is a universal research tool, but in every field humanitarian has its content and operational-cognitive orientation. It is widely used in experimental and historical-pedagogical studies, in particular, it is one of the main in comparative pedagogy.

Being closely related to the general scientific method of comparison, the historical - comparative method designs the consideration of certain phenomena in the dynamics, development. It is based on the analogy - method-reception, which allows, based on the similarity of some features of the objects being compared, to assert the similarity of their other characteristics. The application of this method in the study of a biography will help to identify, on the basis of a limited range of facts, its essential features, when they are not explicit, and to ascertain general and repetitive, necessary and logical in its development. It gives the opportunity to «go beyond» the investigated person and on the basis of analogy to consider it in the broad context of pedagogical thought and through the prism of parallels with its other representatives. Thus, gaps are filled and a holistic image of a biography is formed.

The historical - comparative method has some limitations, therefore its application requires observance of certain methodological requirements. It allows comparing pedagogical biographies that exist both at one, and at different stages of development, but in this case, in the first case, their essential characteristics must be disclosed on the basis of similarity, and in the second - the differences. The comparison should be carried out not on the formal features of similarity, but on the basis of real facts, convincing arguments that reflect the essential features, the properties of personalities, their creative ideas.

The historical - comparative method defines two methodologically important aspects of research in the field of pedagogical biography. The first concerns the study of a person in the universal coordinate system through the use of two opposite approaches: 1) a synchronous («horizontal cut»), which projects its analysis in a specific time period (to evaluate through relationships and comparisons with contemporaries, etc.); 2) diachronic (Greek -»through time»), which projects the study of personalities in a time «vertical», in particular, allows you to track the sequence of personal formation, the evolution of its creative ideas and views, to find out their imitation of predecessors and influences on successors, to identify their heredity, mutual influence, borrowing, etc.

The second aspect relates to proper periodization as a pivotal component of historical pedagogical and biographical research. Despite such important functional and cognitive abilities, the methodology of the humanities does not have a clear definition of the status of periodization, hence it is interpreted as «research technology», «approach», «type of classification» as well as a «method» that we consider to be the most justifiable.

Proceeding from the analysis of various scientific reflections of this phenomenon, adequate and productive, we consider somewhat allegorical consideration of periodization as a «basic design» of a certain scheme (skeleton)», on which «the multiplicity of events» is nurtured as the results of cognitive activity in the form of «facts-knowledge». In aggregate, they give a certain image of the investigated phenomenon, acting as an object of periodization - the object of knowledge (Popova T. N., 2002).

Susceptible and productive is the interpretation of periodization as an instrument of knowledge, which helps to study the process of transformation of the original image of a particular object. Speaking as a result and generalization of the 
study and as a form of its synthetic type, periodization reflects the logic of the development of the object of knowledge, therefore, becomes an effective «formula» and a methodological tool for the cognitive activity of the scientist. This requires taking into account the following components of periodization, such as:

a) object - a phenomenon - process, considered in its development and through division at certain intervals of time;

b) the subject is a time interval that reflects the specifics of the course of historical time and is expressed in the appropriate categories «period», «stage», «phase», «cycle», «stage», «century», «day», etc.

c) attribution, that is, the nomination of a certain time interval according to the defining features of the research object (citation. for: Volikova M., 2015, p. 92-93).

There are also outlined and other contours of the periodization problem can be argued that in the study of pedagogical biography, it can have three main varieties: a) the overall periodization of the historical process, which determines the background, factors of the formation of the person and gives benchmarks for the periodization of its life; b) periodization of the way of life of the figure; c) periodization of individual components of a biography (professional or creative activity, etc.). These varieties can be developed individually or in interdependence or as subordinate.

Periodization should not be idealized as an instrument and tool of scientific and cognitive activity, since each type of comparison and systematization suffers from a certain one-sidedness, a divergence with reality, and therefore often simplifies and «aggravates» reality. In order to minimize these disadvantages and increase the scientific and heuristic effectiveness of this method, it is appropriate to take into account certain general methodological rules and procedures, in particular those developed in the historical science, in developing the periodization of the life path (biography) (Teoryja y metodologhyja ystoryy, 2014, p. 391-392). Firstly, when determining the same taxonomic units - periods, stages, etc., the same criteria should be followed. Biographers often ignore this requirement, defining the periods of life of the person for arbitrary, non-regular criteria, for example, then with time education, then by events of personal or professional life, then on milestones of creativity, etc. This leads to eclectic periodizations, which lose their scientific expediency and value. Secondly, when creating multilevel periodizations, defined on the basis of shredding of separate periods, certain stages, stages, phases, etc. should be less taxonomically important, different criteria can be used for their selection.

The correct application of the methodological foundations of these and other historical methods, avoids the various manifestations of dichotomy (Greek «half» and "divide", in this case, refers to the wrongfulness of division) in a pedagogical and biographical study. In particular, in determining the periodization and general processes of the life path development, it is impossible to mix the different values of the group of taxonomic units: «period», «stage», «phase», «cycle», «stage», which denote particular specific segments of time and «century», «decade», «historical moment», «milestone», «day», etc., relating to common chronological boundaries, or symbolic, often abstract, temporal processes and phenomena.

\section{CONCUSSION AND PROSPECTS FOR FURTHER RESEARCH}

Thus, periodization is a basic, universal and compulsory component of a historical and pedagogical biographical study, therefore, in its development should take into account the scientific and methodological developments of other branches of knowledge, especially historical science.

\section{СПИСОК ВИКОРИСТАНИХ ДЖЕРЕЛ}

Волікова. М. (2015). Проблема періодизації та освоєння науково-публіцистичної спадщини А. Макаренка і контексті інноваційного розвитку освіти. Людинознавчі студії. Серія «Педагогіка», 31, 89 - 97.

Ковальченко, И. Д. (2003). Методы исторического исследования. Москва : Наука.

Нагорных, Е. Е. (2002). Метод ретроспекции и его объяснительные возможности. Мировоззрение как социокультурный феномен. Матер. Всеросс. науч. конф. Екатеринбург, 2002. URL: https://superinf.ru/view_helpstud.php?id=3855

Попова, T. H. (2002). Теоретические проблемы периодизации развития исторической науки и еe истории. URL: http:// wwwhistory. univer.kharkov.ua/book/Istoriografichniy_Zbirnyk_5_2002.pdf.

Сухомлинська, О.В. (2002). Періодизація педагогічної думки в Україні: кроки до нового виміру. Зб. наук. пр. до 10-річчя АПН України, 1, $37-54$.

Теория и методология истории: учебник для вузов. (2014). Волгоград: Учитель.URL:ihaefe.org/files/publications/full/ theorymetod-history.pdf.

\section{REFERENCES}

Volikova, M. (2015). Problema periodyzaciji ta osvojennja naukovo-publicystychnoji spadshhyny A. Makarenka i konteksti innovacijnogho rozvytku osvity. Ljudynoznavchi studiji. Serija «Pedaghoghika», 31, 89 - 97.

Kovaljchenko, Y. D. (2003). Metody ystorycheskogho yssledovanyja. Moskva : Nauka.

Naghornykh, E. E. (2002). Metod retrospekcyy y egho objasnyteljnye vozmozhnosty. Myrovozzrenye kak socyokuljturnyj fenomen. Mater. Vseross. nauch. konf. Ekaterynburgh, 2002. Retrieved from: https://superinf.ru/view_helpstud.php?id=3855

Popova, T. N. (2002). Teoretycheskye problemy peryodyzacyy razvytyja ystorycheskoj nauky y ee ystoryy. Retrieved from: http:// wwwhistory.univer.kharkov.ua/book/ Istoriografichniy_Zbirnyk 5_2002.pdf.

Sukhomlynsjka, O.V. (2002). Periodyzacija pedaghoghichnoji dumky v Ukrajini: kroky do novogho vymiru. Zb. nauk. pr. do 10-richchja APN Ukrajiny, 1, $37-54$.

Teoryja y metodologhyja ystoryy: uchebnyk dlja vuzov. (2014). Volghoghrad: Uchytelj. Retrieved from: ihaefe.org/files/publications/ full/theory-metod-history.pdf. 